\title{
Role of Type 1 Inositol 1,4,5-triphosphate Receptors in Mammalian Oocytes
}

\author{
†Sook Young Yoon \\ Fertility Center of CHA Gangnam Medical Center, CHA University, Seoul 06125, Korea
}

\begin{abstract}
The ability of oocytes to undergo normal fertilization and embryo development is acquired during oocyte maturation which is transition from the germinal vesicle stage (GV), germinal vesicle breakdown (GVBD) to metaphase of meiosis II (MII). Part of this process includes redistribution of inositol 1, 4, 5-triphosphate receptor (IP3R), a predominant Ca ${ }^{2+}$ channel on the endoplasmic reticulum membrane. Type 1 IP3R (IP3R1) is expressed in mouse oocytes dominantly. At GV stage, IP3R1 are arranged as a network throughout the cytoplasm with minute accumulation around the nucleus. At MII stage, IP3R1 diffuses to the entire cytoplasm in a more reticular manner, and obvious clusters of IP3R1 are observed at the cortex of the egg. This structural reorganization provides acquisition of $\left[\mathrm{Ca}^{2+}\right]_{\mathrm{i}}$ oscillatory activity during fertilization. In this review, general properties of IP3R1 in somatic cells and mammalian oocyte are introduced.
\end{abstract}

Key words : IP3R1, Oocytes, Fertilization, PLCzeta

Increase of intracellular free calcium concentration $\left(\left[\mathrm{Ca}^{2+}\right]_{\mathrm{i}}\right)$ is monitored in various cellular response to stimuli (Berridge et al., 2000). $\left[\mathrm{Ca}^{2+}\right]_{\mathrm{i}}$ increases is observed in most of cellular response such as secretion and contraction, proliferation, differentiation, fertilization, development and cell death (Berridge et al., 2003). Fertilization of mammalian oocytes, one of the cellular event, is controlled by increase in $\left[\mathrm{Ca}^{2+}\right]_{\mathrm{i}}$ with oscillation pattern that persists for several hours from sperm-egg fusion (Miyazaki et al., 1993). These $\left[\mathrm{Ca}^{2+}\right]_{\mathrm{i}}$ oscillations are responsible for the initiation of fertilization event including, cortical granule exocytosis to block to polyspermy, resumption of meiosis, recruitment of maternal mRNAs and activation of embryonic genome, and further embryonic development (Ajduk et al., 2008). Most $\mathrm{Ca}^{2+}$-increase during fertilization origi- nates from intracellular calcium store via 1, 4, 5 inositol triphosphate (IP3) receptors (IP3R) on the endoplasmic reticulum membrane. IP3 is a widespread signaling molecule produced as a result of hydrolysis of phosphatidylinositol 4, 5-bisphosphate $\left(\mathrm{PIP}_{2}\right)$ by phospholipase C (PLC) (Lee et al., 2006b). Egg has reported to express all three isoforms of IP3R, but type 1 IP3R (IP3R1) is present significantly larger amount in mammalian eggs (He et al., 1999). This review is to introduce the general information of IP3R and role of IP3R in mammalian egg fertilization.

\section{$\left[\mathrm{Ca}^{2+}\right]_{\mathrm{i}}$ OSCILLATION DURING FERTILIZATION}

Fertilization is a process which is regulated by IP3-

\footnotetext{
Manuscript received January 10, 2019, Received in revised form February 17, 2019, Accepted February 27, 2019

${ }^{\dagger}$ Corresponding Author : Sook Young Yoon, Fertility Center of CHA Gangnam Medical Center, CHA University, Seoul 06125, Korea. Tel: +82-2-34682841, E-mail: syyoon11@cha.ac.kr creative-commons.org/licenses/by-nc/3.0) which permits unrestricted non-commercial use, distribution, and reproduction in any medium, provided the original work is properly cited.
} 
mediated $\mathrm{Ca}^{2+}$-release from intracellular $\mathrm{Ca}^{2+}$-store. In mammalian oocytes, the sperm factor (SF, now it has been as known phospholipase $\mathrm{C}$ zeta, $\mathrm{PLC} \zeta$ ) triggers activation of phosphoinositide (PI) pathway that produces IP3 and 1, 2-diacylglycerol (DAG) by hydrolysis of PIP2. Increase intracellular IP3 concentration is in charge for mediating $\mathrm{Ca}^{2+}$-release from endoplasmic reticulum (ER) via IP3 receptor (Fig. 1) (Miyazaki et al., 1993; Malcuit et al., 2005; Malcuit et al., 2006; Yoon, 2011). Microinjection of 18A10 antibody, which recognizes an epitope to the $\mathrm{Ca}^{2+}$ channel region in the C-terminus of IP3R1, or IP3R antagonist inhibits $\left[\mathrm{Ca}^{2+}\right]_{\mathrm{i}}$ oscillation in fertilized oocytes (Miyazaki et al., 1992). Also, adenophostin A, agonist of IP3R, or thimerosal, a thiol oxidizing agent, induced $\left[\mathrm{Ca}^{2+}\right]_{i}$ oscillation and further egg activation process in mature oocytes without sperm (Fissore et al., 1992; Jellerette et al., 2000).

\section{GENERAL STRUCTURE OF IP3RI}

IP3, as an intracellular second messenger, mediating
$\mathrm{Ca}^{2+}$-signalling in cellular response was first reported in neutrophils (Prentki et al., 1984). Autoradiographic studies with $\left[{ }^{3} \mathrm{H}\right]$ IP3 represented high densities of IP3 binding in cerebellum with 100-300 times higher than in peripheral tissues (Worley et al., 1987). The purification of IP3R was reported $260 \mathrm{KDa}$ protein band by electrophoretic analysis, purified protein presented seletivity for IP3 over other inositol phosphates (Supattapone et al., 1988). Three isoforms of IP3R (type 1, type 2, and type 3) have been identified by cDNA cloning. Most cells express at least one isoform and type 1 IP3R (IP3R1) is the most widely expressed in all cell types and all developmental stages (Marks, 1997).

The three IP3R isoforms demonstrate different IP3binding affinities and sencitivity. The overall domain structure of IP3R contains a cytoplasmic N-terminus, IP3 binding domain, regulatory or modulatory domain which has multiple regulatory sites for $\mathrm{Ca}^{2+}$, calmodulin dependent protein kinase, and other regulatory protein (Fig. 2). The C-terminus is channel domain including six transmembrane
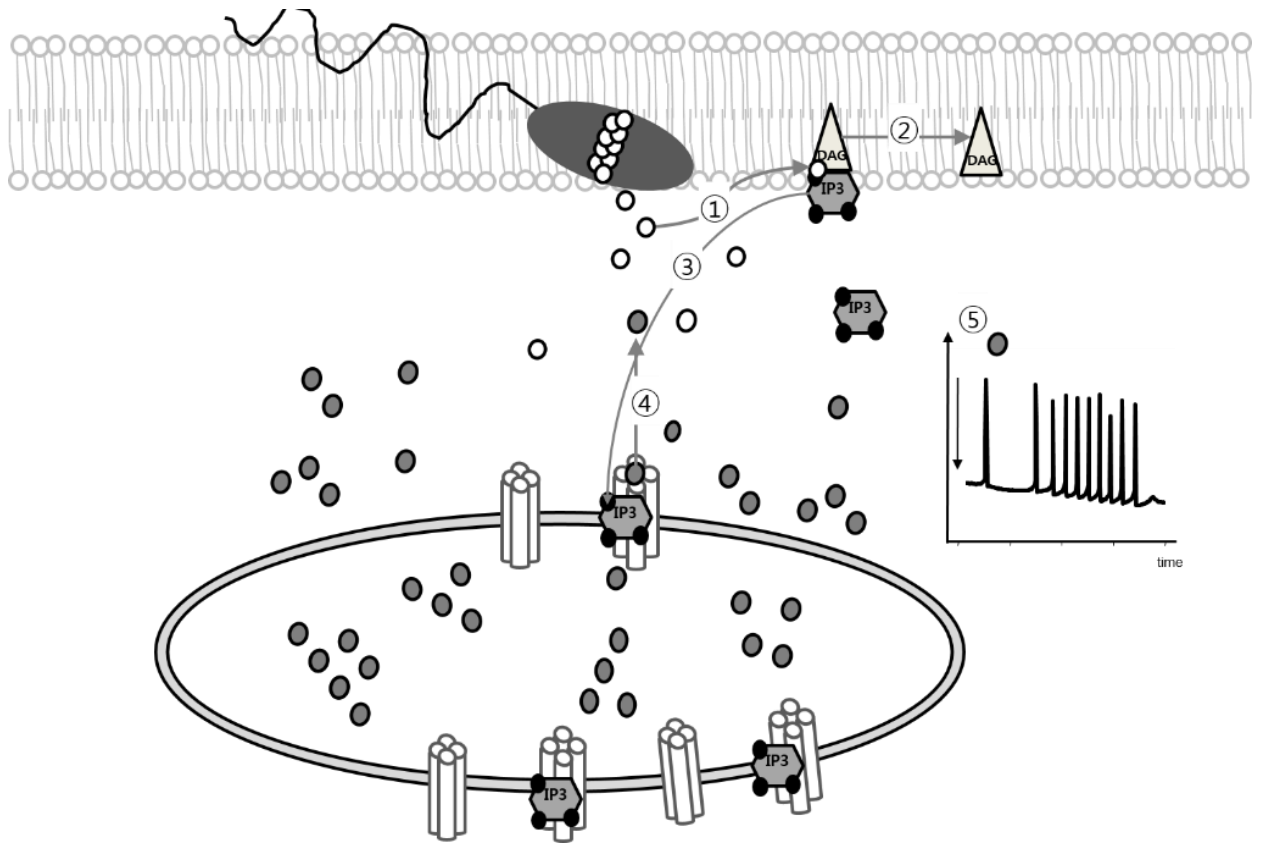

Fig. 1. Role of IP3R1 during fertilization in mammalian oocytes. (1) PLC ל̧ hydrolyzes PIP2 to DAG (3)) and IP3, (2) IP3 binds to IP3R1 on the endoplasmic reticulum, (4) Activated IP3R1 releases $\mathrm{Ca}^{2+}$ from ER to cytoplasm, (5) Ca ${ }^{2+}$ oscillation in the cytoplasm. 


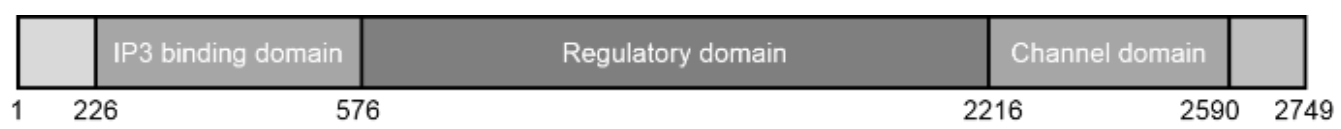

Fig. 2. Overall structure of IP3R.

domains (TMD), which form $\mathrm{Ca}^{2+}$-release channels on the endoplasmic reticulum membrane (Lee et al., 2006b).

Using electron microscopy analysis, IP3R was observed tetrameric structure with reversible transition between two distinct structure, windmill and square structure (Hamada et al., 2002).

\section{ACTIVATION OF IP3R}

$\mathrm{Ca}^{2+}$-release through IP3R is known to be modulated by posttranslational modification of IP3R including, binding with IP3 and $\mathrm{Ca}^{2+}$, clustering of IP3R, phosphorylation / dephosphorylation, and spatial distribution in the cytoplasm.

Activation of IP3R is begun by IP3 binding to the IP3 binding domain (amino acid 226-576) and $\mathrm{Ca}^{2+}$ ion permeating. At least four IP3 binding sites of the tetrameric structure of IP3R are essential to activate for IP3R (Taylor $\&$ Tovey, 2010). In addition, cytosolic $\mathrm{Ca}^{2+}$ was shown to regulate IP3, however, the effects of $\mathrm{Ca}^{2+}$ were biphasic. The modest increase of intracellular $\mathrm{Ca}^{2+}$ induces the enhancing response to IP3, while higher increase have inhibitory effects in IP3R1 through patch clamp electrophysiology of isolated Xenopus oocyte nuclei membrane (Mak et al., 2003). At least eight $\mathrm{Ca}^{2+}$-binding sites have been identified in IP3R $1, \mathrm{Ca}^{2+}$ promotes the transition from the square (or mushroom-like structure) to the windmill structure with relocation of four pheripheral IP3 binding domains (Hamada et al., 2003).

\section{Clustering of IP3R}

A commom consequence of activation of IP3R is the formation of IP3R clusters. IP3R clustering in somatic cells has been known to temporarily concur with increases in the cytosolic IP3 rathar than with $\left[\mathrm{Ca}^{2+}\right]_{\mathrm{i}}$ (Lee et al., 2006b). Green fluorecence protein-tagged IP3R1 was expressed on the rat hippocampal neuron in vitro, and its lateral diffusion was regulated by actin filaments and $4.1 \mathrm{~N}$ proteins, cytoskeletal-associated proteins enriched in neuron (Fukatsu et al., 2004). Single IP3R response first, then clustered IP3Rs open togerther with local $\mathrm{Ca}^{2+}$-puff, then all puffs lead to a global regenerative $\mathrm{Ca}^{2+}$ waves that spread out through whole cytoplasm in general somatic cells (Rahman, 2009, 2012). This IP3R clustering induced by IP3 production in the absence of a significant $\mathrm{Ca}^{2+}$ increase, but elevated $\mathrm{Ca}^{2+}$ without IP3 production did not induce IP3R clustering (Tateishi et al., 2005).

\section{Phosphorylation/dephosphorylation of IP3R in} general cellular response

IP3R isoforms have multiple phosphorylation consensus sites and several docking sites for protein kinase and phosphatases on their sequences. Today at least 12 different protein kinases are investigated.

\section{1) Protein kinase $A(P K A)$}

PKA phosphorylates two distinct sites on IP3R1 ( $\mathrm{S}^{1588}$ and $\mathrm{S}^{1755}$ ) in the regulatory region, and phosphorylation of this sites regulates channel open probability of IP3R1 in whole cell patch clamp study (Wagner et al., 2008). Association of IP3R1 with protein phosphatase 1 alpha facilitates dephosphorylation of PKA mediated phosphorylation (Tang et al., 2003). Also, involvement of PKA to IP3R1 activation is mediated by leucine / isoleucine zipper domain in the regulatory region (Tu et al., 2004).

\section{2) Protein kinase G (PKG)}

Another protein kinase $\mathrm{G}$ is shown resticted tissue distribution than PKA, could phosphorylate IP3R1 $\left(\mathrm{Ser}^{696}\right)$ with 
IP3R-associated cGMP kinase substrate (IRAG) in microsomal smooth muscle membranes (Schlossmann et al., 2000).

\section{3) $\mathrm{Ca}^{2+} / \mathrm{CaM}$-dependent protein kinase II}

$\mathrm{Ca}^{2+} / \mathrm{CaM}$-dependent protein kinase II (CaM KII) is a serine / threonin protein kinase expressed as an 8-12 monomers in most tissues, and highly sensitive to $\mathrm{Ca}^{2+}$ and calmodulin. Also it has been shown as $\mathrm{Ca}^{2+}$-oscillation decoder in varioius cellular response (Dupont \& Goldbeter, 1998). All three different CaM KII inhibitors (KN-93, KN62, and Autocamtide - 2 - Related Inhibitory Peptide (AIP)) inhibited ATP-mediated $\left[\mathrm{Ca}^{2+}\right]_{\mathrm{i}}$ transient in calf pulmonary artery endothelial in vitro (Aromolaran \& Blatter, 2005). Colocalizatioin of CaM KII and IP3R have reported in several tissues, this interaction induced phosphorylation of IP3R within N-terminal region. Besides, this phorylation of IP3R significantly decrease the open probability in lipid bilayers. It may suggest CaM KII acts on $\mathrm{Ca}^{2+}$ oscillations negatively (Zima et al., 2007).

\section{4) Protein kinase $C(P K C)$}

The actilvity of conventional PKCs, including $\alpha, \beta$, and $\gamma$, depend on $\mathrm{Ca}^{2+}$ and diacylgylcerol. Also, PKC activation lead to changes of subcellular localization of IP3Rs in many cell types (Vermassen et al., 2003). Phosphorylation sites for $\mathrm{PKC}$ on IP3R is $[\mathrm{R} / \mathrm{K}]-\mathrm{X}-[\mathrm{S} / \mathrm{T}]-\mathrm{X}-[\mathrm{R} / \mathrm{K}]$, and counteracts by phosphatase calcineurin (Cameron et al., 1995). In addition, there are several protein to interact with PKC for IP3R activation, FKBP12, mTOR and RACK1.

\section{5) Protein kinase $B(P K B)$}

All three IP3R isoforms contain an R-X-R-X-X-[S/T] consensus site for $\mathrm{PKB}$ in their $\mathrm{C}$-terminal. $\mathrm{PKB}$ have a survival effects on apoptosis by inhibiting IP3-induced $\mathrm{Ca}^{2+}$ release on $\mathrm{S}^{2681}$ (Joseph \& Hajnoczky, 2007).

\section{6) Cyclin-dependent protein kinases (CDKs)}

Cyclin-dependent kinases (CDKs) are a family of protein kinases and involved in cell cycle, including extracellular signal regulated kinase (ERK), and polo like kinase.

A well investigated cellular system, mammalian oocytes, was showed these protein kinases activity changes during oocyte maturation. Increase of $\left[\mathrm{Ca}^{2+}\right]_{i}$ during fertilization has been reported IP3R mediated $\mathrm{Ca}^{2+}$ release with single, large $\mathrm{Ca}^{2+}$ increase followed by $\mathrm{Ca}^{2+}$ oscillation for several hours until pronuclear formation. These $\mathrm{Ca}^{2+}$ changes depend on IP3R activity through protein kinase activity. CDKs (cdc2) assemble with the regulatory protein cyclin $\mathrm{B}$ to form the maturation promoting factor, which is major protein for starting of oocyte maturation (Polanski et al., 2012). CDK1 phosphorylates IP3R1 at $S^{421}$, in IP3 binding domain and $\mathrm{T}^{799}$ in regulatory domain. Both sites are conserved in IP3R1 from human to Drosophila (Lee et al., 2006b). During oocyte maturation, IP3R1 undergoes cell cycle-dependent phosphorylation in mouse oocytes, Mphase kinases associates as regulators of IP3R1 in mammalian egg (Jellerette et al., 2004). CDK1/cyclin B mediated IP3R1 phosphorylation at $\mathrm{T}^{799}$ increases IP3 binding activity, resulting in an increase $\mathrm{Ca}^{2+}$-releasing activity.

ERK1 and ERK2 are cell cycle dependent kinases and phosphorylate an P-X-[S/T]-P. In mouse IP3R1 has three ERK1/2 phosphorylation sites for ERK1/2 at $\mathrm{S}^{436}, \mathrm{~T}^{945}$ and $\mathrm{S}^{1765}$. From in vitro phosphorylation studies represent that ERK2 phosphorylates IP3R1 at $\mathrm{S}^{436}$, that mutation (S436A) abrogates IP3R1 phosphorylation (Lee et al., 2006a).

\section{7) Tyrosine kinases}

Phosphorylation of tyrosine residues of IP3R1 was observed in T-cell receptor activation, the IP3R phosphorylation is induced by tyrosine kinase, Fyn at $\mathrm{Y}^{353}$. This phosphorylation was reduced in thymocytes in fyn-/- mice (Jayaraman et al., 1996). In T-cell activation, IP3R phosphorylation by Fyn induces increase of affinity for IP3 to a 5 times, which means that IP3R1 can continue to release $\mathrm{Ca}^{2+}$ from intracellular $\mathrm{Ca}^{2+}$ store during the reducing of intracellular IP3 (Cui et al., 2004). 


\section{8) Anti-apoptotic $\mathrm{Bcl}-2$ protein}

B-cell lymphoma 2 (Bcl-2), encoded in humans by the $B c l 2$ gene, is a proapoptotic and anti-apoptotic protein with four BH domain and embedded in the endoplasmic reticulum, nuclear envelope, and mitochondrial outer membrane (Greenberg et al., 2014). Bcl-2 proteins have been associated on PKA mediated phophorylation.

\section{CHANGES OF IP3R1 DURING OOCYTE MATURATION IN MAMMALS}

Multiple changes in $\mathrm{Ca}^{2+}$-response mechanism via IP3R1 including IP3R1 clustering on the plasma membrane (Mehlmann \& Kline, 1994; Mehlmann et al., 1996; Machaca, 2004; Sun et al., 2011), phosphorlation of IP3R1 (Vanderheyden et al., 2009; Wakai et al., 2012; Zhang et al., 2015), have been described during oocyte maturation.

\section{Type of IP3R in mammalian oocytes}

As IP3R1 is observed in whole cytoplasm, 1.9 fold maturation associated increase was indicated by western blot analysis, in contrast, the type 2 and the type 3 IP3R were detect lesser in oocytes than IP3R1 (Fissore et al., 1999).

\section{Mass of IP3R1 protein in oocytes}

During the mouse oocyte maturation, it has known to increase an sensitivity to IP3 mediated release of intracellular calcium. 1.5 to 2 fold maturation associated increase in the mass of IP3R1 (Fissore et al., 1999) stands for this increase in IP3 sensitivity, and administrated dsRNA corresponding to the IP3R1 sequence into germinal vesicle (GV) immature oocytes and resulted in the mass of IP3R1 protein and significantly decreased $\mathrm{Ca}^{2+}$ transients in these oocytes than controls (Xu et al., 2003).

\section{Subcellular localization, clustering and regulation} of IP3R1 function in mammalian egg

The sensitivity of $\mathrm{Ca}^{2+}$ release has known to increase during oocyte maturation from GV stage to MII stage (Mehlmann \& Kline, 1994; Mehlmann et al., 1996). In immature GV oocytes showed homogeneous distribution of IP3R1 on entire cytoplasm except geminal vesigle. However, during oocyte maturation, IP3R1 reorganized their localization and clustering itself. Most of the IP3R1 distributed in whole cytoplasm with cortical clusters near plasma membrane in large clusters, 1-2 $\mu \mathrm{m}$ in diameter (yellow arrow in Fig. 3) (Mehlmann et al., 1996). Inhibition of this clustering by MEK-specific inhibitor, U0126, reduced phosphorylation of IP3R1 and calcium release during fertilization (Lee et al., 2006a; Ito et al., 2008). Changes in IP3R1 sensitivity may underline the changes of the spatio-temporal $\mathrm{Ca}^{2+}$ responses during oocyte maturation. The conductivity of IP3R1 to $\mathrm{Ca}^{2+}$ in response to increase in IP3 is enhanced at mature MII oocytes (Machaca, 2007; Ullah et al., 2007). The $\mathrm{Ca}^{2+}$ transient by PLC $\zeta$ in GV showed very small and narrow spike, however, that in mature MII oocytes showed big and long (4-5 mins) spike

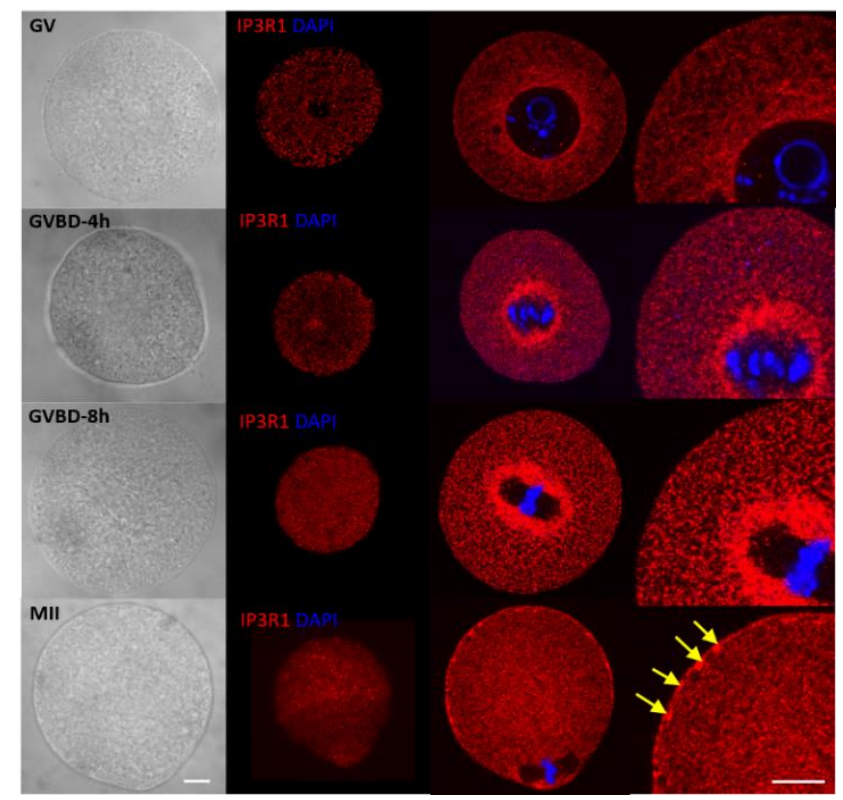

Fig. 3. IP3R1 distribution in GV, GVBD and MII mouse oocytes. GVBD oocytes were cultured for $4 \mathrm{hr}$, or 8 $\mathrm{hr}$ in vitro. Arrows indicate cortical clusters more than $1 \mu \mathrm{m}$ in diameter. Scale bar $=10 \mu \mathrm{m}$. GV, germinal vesicle; GVBD, germinal vesicle breakdown. 
in mouse oocytes (Machaca, 2007). Also $\mathrm{Ca}^{2+}$-oscillations in response to sperm of immature oocytes were maximum three much smaller transients, which ceased after $1 \mathrm{hr}$. But the oscillation of $\mathrm{Ca}^{2+}$ in mature oocytes by sperm continued for 4 to $5 \mathrm{hrs}$, near pronuclear (PN) formation (Jones et al., 1995a; Jones et al., 1995b). These sensitivity of $\mathrm{Ca}^{2+}$ response is controlled by $\mathrm{M}$ phase kinase during oocyte maturation with cell cycle dependent (Jones et al., 1995a; Jellerette et al., 2004). During oocyte maturation $\mathrm{GV}$ immature oocytes have nonphosphorylated form of IP3R1, on the other hands, MII mature oocytes have phosphorylated IP3R1 on $\mathrm{S}^{436}$ by MAPK, and $\mathrm{S}^{421}, \mathrm{~T}^{799}$ (Lee et al., 2006b; Zhang et al., 2015).

\section{IP3R1 degradation during fertilization}

In mammalian oocytes, fertilization mediated $\mathrm{Ca}^{2+}$ oscillations are very active at the beginning of fertilization, which is ceased as zygotes come close to the pronuclear stage. Further, more than $50 \%$ of IP3R1 mass is downregulated by PN stage (Brind et al., 2000; Jellerette et al., 2000; Jones, 2005). These IP3R1 degradation requires continuous identical and persistantly elevated levels of IP3 by PLC $\zeta$ (Jellerette et al., 2000). Also continuous degradation of the IP3R1 results in $\mathrm{Ca}^{2+}$-oscillation with reduced periodicity (Lee et al., 2010). Degradation of IP3R1 is mediated by ubiquitin-proteasome pathway after IP3 binding in intact mammalian cells (Alzayady \& Wojcikiewicz, 2005).

\section{CONCLUSION}

The generating of $\mathrm{Ca}^{2+}$-release during fertilization provides the widespread intracellular signaling for egg activation and further embryonic development. In mammalian oocytes, $\mathrm{Ca}^{2+}$ oscillation during fertilization persists for several hours until the pronuclear formation. Here we interpret general charateristic of IP3R1 and the role of IP3R1 during fertilization. Further studis should be inves- tigated the molecular mechanism that controls the activation and degradation of IP3R1 in egg activation and further embryonic development. It is hoped that this work will helpful the understanding of physiological problem in infertility or subfertility patients.

\section{ACKNOWLEDGMENTS}

This research was supported by Basic Science Research Program through the National Research Foundation of Korea (NRF) funded by the Ministry of Education (NRF2014R1A1A2056914).

\section{REFERENCES}

Ajduk A, Malagocki A, Maleszewski M (2008) Cytoplasmic maturation of mammalian oocytes: Development of a mechanism responsible for sperm-induced $\mathrm{Ca}^{2+}$ oscillations. Reprod Biol 8:3-22.

Alzayady KJ, Wojcikiewicz RJH (2005) The role of $\mathrm{Ca}^{2+}$ in triggering inositol 1,4,5-trisphosphate receptor ubiquitination. Biochem J 392:601-606.

Aromolaran AAS, Blatter LA (2005) Modulation of intracellular $\mathrm{Ca}^{2+}$ release and capacitative $\mathrm{Ca}^{2+}$ entry by CaMKII inhibitors in bovine vascular endothelial cells. Am J Physiol Cell Physiol 289:C1426-C1436.

Berridge MJ, Bootman MD, Roderick HL (2003) Calcium signalling: Dynamics, homeostasis and remodelling. Nat Rev Mol Cell Biol 4:517-529.

Berridge MJ, Lipp P, Bootman MD (2000) The versatility and universality of calcium signalling. Nat Rev Mol Cell Biol 1:11-21.

Brind S, Swann K, Carroll J (2000) Inositol 1,4,5-trisphosphate receptors are downregulated in mouse oocytes in response to sperm or adenophostin A but not to increases in intracellular $\mathrm{Ca}^{2+}$ or egg activation. Dev Biol 223:251-265.

Cameron AM, Steiner JP, Roskams AJ, Ali SM, Ronnett 
GV, Snyder SH (1995) Calcineurin associated with the inositol 1,4,5-trisphosphate receptor-FKBP12 complex modulates $\mathrm{Ca}^{2+}$ flux. Cell 83:463-472.

Cui J, Matkovich SJ, deSouza N, Li S, Rosemblit N, Marks AR (2004) Regulation of the type 1 inositol 1, 4,5-trisphosphate receptor by phosphorylation at tyrosine 353. J Biol Chem 279:16311-16316.

Dupont G, Goldbeter A (1998) CaM kinase II as frequency decoder of $\mathrm{Ca}^{2+}$ oscillations. Bioessays 20:607-610.

Fissore RA, Dobrinsky JR, Balise JJ, Duby RT, Robl JM (1992) Patterns of intracellular $\mathrm{Ca}^{2+}$ concentrations in fertilized bovine eggs. Biol Reprod 47:960-969.

Fissore RA, Longo FJ, Anderson E, Parys JB, Ducibella T (1999) Differential distribution of inositol trisphosphate receptor isoforms in mouse oocytes. Biol Reprod 60:49-57.

Fukatsu K, Bannai H, Zhang S, Nakamura H, Inoue T, Mikoshiba K (2004) Lateral diffusion of inositol 1,4,5trisphosphate receptor type 1 is regulated by actin filaments and $4.1 \mathrm{~N}$ in neuronal dendrites. J Biol Chem 279:48976-48982.

Greenberg EF, Lavik AR, Distelhorst CW (2014) Bcl-2 regulation of the inositol 1,4,5-trisphosphate receptor and calcium signaling in normal and malignant lymphocytes: Potential new target for cancer treatment. Biochim Biophys Acta 1843:2205-2210.

Hamada K, Miyata T, Mayanagi K, Hirota J, Mikoshiba K (2002) Two-state conformational changes in inositol 1,4,5-trisphosphate receptor regulated by calcium. J Biol Chem 277:21115-21118.

Hamada K, Terauchi A, Mikoshiba K (2003) Three-dimensional rearrangements within inositol 1,4,5-trisphosphate receptor by calcium. J Biol Chem 278:5288152889.

He CL, Damiani P, Ducibella T, Takahashi M, Tanzawa K, Parys JB, Fissore RA (1999) Isoforms of the inositol 1,4,5-trisphosphate receptor are expressed in bovine oocytes and ovaries: The type-1 isoform is down-re- gulated by fertilization and by injection of adenophostin A. Biol Reprod 61:935-943.

Ito J, Yoon SY, Lee B, Vanderheyden V, Vermassen E, Wojcikiewicz R, Alfandari D, De Smedt H, Parys JB, Fissore RA (2008) Inositol 1,4,5-trisphosphate receptor 1, a widespread $\mathrm{Ca}^{2+}$ channel, is a novel substrate of polo-like kinase 1 in eggs. Dev Biol 320:402-413.

Jayaraman T, Ondrias K, Ondria E, Marks AR (1996) Regulation of the inositol 1,4,5-trisphosphate receptor by tyrosine phosphorylation. Science 272:1492-1494.

Jellerette T, He CL, Wu H, Parys JB, Fissore RA (2000) Down-regulation of the inositol 1,4,5-trisphosphate receptor in mouse eggs following fertilization or parthenogenetic activation. Dev Biol 223:238-250.

Jellerette T, Kurokawa M, Lee B, Malcuit C, Yoon SY, Smyth J, Vermassen E, De Smedt H, Parys JB, Fissore RA (2004) Cell cycle-coupled $\left[\mathrm{Ca}^{2+}\right](\mathrm{i})$ oscillations in mouse zygotes and function of the inositol 1,4,5trisphosphate receptor-1. Dev Biol 274:94-109.

Jones KT (2005) Mammalian egg activation: From $\mathrm{Ca}^{2+}$ spiking to cell cycle progression. Reproduction 130:813823.

Jones KT, Carroll J, Merriman JA, Whittingham DG, Kono $\mathrm{T}$ (1995a) Repetitive sperm-induced $\mathrm{Ca}^{2+}$ transients in mouse oocytes are cell cycle dependent. Development 121:3259-3266.

Jones KT, Carroll J, Whittingham DG (1995b) Ionomycin, thapsigargin, ryanodine, and sperm induced $\mathrm{Ca}^{2+}$ release increase during meiotic maturation of mouse oocytes. J Biol Chem 270:6671-6677.

Joseph SK, Hajnoczky G (2007) IP3 receptors in cell survival and apoptosis: $\mathrm{Ca}^{2+}$ release and beyond. Apoptosis 12:951-968.

Lee B, Vermassen E, Yoon SY, Vanderheyden V, Ito J, Alfandari D, De Smedt H, Parys JB, Fissore RA (2006a) Phosphorylation of IP3R1 and the regulation of $\left[\mathrm{Ca}^{2+}\right]_{\mathrm{i}}$ responses at fertilization: A role for the MAP kinase pathway. Development 133:4355-4365. 
Lee B, Yoon SY, Fissore RA (2006b) Regulation of fertilization-initiated $\left[\mathrm{Ca}^{2+}\right]_{i}$ oscillations in mammalian eggs: A multi-pronged approach. Semin Cell Dev Biol 17:274-284.

Lee B, Yoon SY, Malcuit C, Parys JB, Fissore RA (2010) Inositol 1,4,5-trisphosphate receptor 1 degradation in mouse eggs and impact on $\left[\mathrm{Ca}^{2+}\right]_{i}$ oscillations. J Cell Physiol 222:238-247.

Machaca K (2004) Increased sensitivity and clustering of elementary $\mathrm{Ca}^{2+}$ release events during oocyte maturation. Dev Biol 275:170-182.

Machaca K (2007) $\mathrm{Ca}^{2+}$ signaling differentiation during oocyte maturation. J Cell Physiol 213:331-340.

Mak DOD, McBride SMJ, Petrenko NB, Foskett JK (2003) Novel regulation of calcium inhibition of the inositol 1,4,5-trisphosphate receptor calcium-release channel. J Gen Physiol 122:569-581.

Malcuit C, Knott JG, He C, Wainwright T, Parys JB, Robl JM, Fissore RA (2005) Fertilization and inositol 1,4,5trisphosphate (IP3)-induced calcium release in type-1 inositol 1,4,5-trisphosphate receptor down-regulated bovine eggs. Biol Reprod 73:2-13.

Malcuit C, Kurokawa M, Fissore RA (2006) Calcium oscillations and mammalian egg activation. J Cell Physiol 206:565-573.

Marks AR (1997) Intracellular calcium-release channels: Regulators of cell life and death. Am J Physiol 272:H597-H605.

Mehlmann LM, Kline D (1994) Regulation of intracellular calcium in the mouse egg: Calcium release in response to sperm or inositol trisphosphate is enhanced after meiotic maturation. Biol Reprod 51:1088-1098.

Mehlmann LM, Mikoshiba K, Kline D (1996) Redistribution and increase in cortical inositol 1,4,5-trisphosphate receptors after meiotic maturation of the mouse oocyte. Dev Biol 180:489-498.

Miyazaki S, Shirakawa H, Nakada K, Honda Y (1993) Essential role of the inositol 1,4,5-trisphosphate receptor/
$\mathrm{Ca}^{2+}$ release channel in $\mathrm{Ca}^{2+}$ waves and $\mathrm{Ca}^{2+}$ oscillations at fertilization of mammalian eggs. Dev Biol 158:62-78.

Miyazaki S, Yuzaki M, Nakada K, Shirakawa H, Nakanishi S, Nakade S, Mikoshiba K (1992) Block of $\mathrm{Ca}^{2+}$ wave and $\mathrm{Ca}^{2+}$ oscillation by antibody to the inositol $1,4,5$ trisphosphate receptor in fertilized hamster eggs. Science 257:251-255.

Polanski Z, Homer H, Kubiak JZ (2012) Cyclin B in mouse oocytes and embryos: Importance for human reproduction and aneuploidy. Results Probl Cell Differ 55:69-91.

Prentki M, Wollheim CB, Lew PD (1984) $\mathrm{Ca}^{2+}$ homeostasis in permeabilized human neutrophils. Characterization of $\mathrm{Ca}^{2+}$-sequestering pools and the action of inositol 1,4,5-triphosphate. J Biol Chem 259:13777-13782.

Rahman T (2012) Dynamic clustering of IP3 receptors by IP3. Biochem Soc Trans 40:325-330.

Rahman TU, Skupin A, Falcke M, Taylor CW (2009) Clustering of InsP3 receptors by InsP3 retunes their regulation by InsP3 and $\mathrm{Ca}^{2+}$. Nature 458:655-659.

Schlossmann J, Ammendola A, Ashman K, Zong X, Huber A, Neubauer G, Wang GX, Allescher HD, Korth M, Wilm M, Hofmann F, Ruth P (2000) Regulation of intracellular calcium by a signalling complex of IRAG, IP3 receptor and cGMP kinase Ibeta. Nature 404:197201.

Sun L, Yu F, Ullah A, Hubrack S, Daalis A, Jung P, Machaca K (2011) Endoplasmic reticulum remodeling tunes IP3-dependent $\mathrm{Ca}^{2+}$ release sensitivity. PLOS ONE 6:e27928.

Supattapone S, Worley PF, Baraban JM, Snyder SH (1988) Solubilization, purification, and characterization of an inositol trisphosphate receptor. J Biol Chem 263:15301534.

Tang TS, Tu H, Wang Z, Bezprozvanny I (2003) Modulation of type 1 inositol $(1,4,5)$-trisphosphate receptor function by protein kinase a and protein phos- 
phatase 1alpha. J Neurosci 23:403-415.

Tateishi Y, Hattori M, Nakayama T, Iwai M, Bannai H, Nakamura T, Michikawa T, Inoue T, Mikoshiba K (2005) Cluster formation of inositol 1,4,5-trisphosphate receptor requires its transition to open state. J Biol Chem 280:6816-6822.

Taylor CW, Tovey SC (2010) IP(3) receptors: Toward understanding their activation. Cold Spring Harb Perspect Biol 2:a004010.

Tu H, Tang TS, Wang Z, Bezprozvanny I (2004) Association of type 1 inositol 1,4,5-trisphosphate receptor with AKAP9 (Yotiao) and protein kinase A. J Biol Chem 279:19375-19382.

Ullah G, Jung P, Machaca K (2007) Modeling $\mathrm{Ca}^{2+}$ signaling differentiation during oocyte maturation. Cell Calcium 42:556-564.

Vanderheyden V, Wakai T, Bultynck G, De Smedt H, Parys JB, Fissore RA (2009) Regulation of inositol 1,4,5trisphosphate receptor type 1 function during oocyte maturation by MPM-2 phosphorylation. Cell Calcium 46:56-64.

Vermassen E, Van Acker K, Annaert WG, Himpens B, Callewaert G, Missiaen L, De Smedt H, Parys JB (2003) Microtubule-dependent redistribution of the type-1 inositol 1,4,5-trisphosphate receptor in A7r5 smooth muscle cells. J Cell Sci 116:1269-1277.
Wagner LE, Joseph SK, Yule DI (2008) Regulation of single inositol 1,4,5-trisphosphate receptor channel activity by protein kinase A phosphorylation. J Physiol 586:3577-3596.

Wakai T, Vanderheyden V, Yoon SY, Cheon B, Zhang N, Parys JB, Fissore RA (2012) Regulation of inositol 1,4,5-trisphosphate receptor function during mouse oocyte maturation. J Cell Physiol 227:705-717.

Worley PF, Baraban JM, Colvin JS, Snyder SH (1987) Inositol trisphosphate receptor localization in brain: Variable stoichiometry with protein kinase C. Nature 325:159-161.

Xu Z, Williams CJ, Kopf GS, Schultz RM (2003) Maturation-associated increase in IP3 receptor type 1: Role in conferring increased IP3 sensitivity and $\mathrm{Ca}^{2+}$ oscillatory behavior in mouse eggs. Dev Biol 254:163-171.

Yoon SY, Kang DW (2011) Production of intracellular calcium oscillation by phospholipase $\mathrm{C}$ zeta activation in mammalian eggs. Dev Reprod 15:197-204.

Zhang N, Yoon SY, Parys JB, Fissore RA (2015) Effect of M-phase kinase phosphorylations on type 1 inositol 1,4,5-trisphosphate receptor-mediated $\mathrm{Ca}^{2+}$ responses in mouse eggs. Cell Calcium 58:476-488.

Zima AV, Bare DJ, Mignery GA, Blatter LA (2007) IP3dependent nuclear $\mathrm{Ca}^{2+}$ signalling in the mammalian heart. J Physiol 584:601-611. 